\section{SURADNJA U INKLUZIVNIM ŠKOLAMA: KAKO POMOĆNICI U NASTAVI PROCJENJUJU NJIHOVU SURADNJU $S$ UČITELIMA U RAZREDU?}

Prethodno priopćenje

Primljeno: ožujak, 2019.

Prihvaćeno: veljača, 2020.

UDK: 371.12

DOI 10.3935/jsr.v27i1.287

Dijana Drandić ${ }^{1}$

https://orcid.org/0000-0003-

0645-4698

Mirjana Radetić

Paić ${ }^{2}$

http://orcid.org/0000-0002-

5256-724X

Sveučilište Jurja Dobrile u Puli Fakultet za odgojne i obrazovne znanosti

Ključne riječi:

inkluzija, odgoj i obrazovanje, socijalizacija, suradnja, učenik s teškoćama.

1 Doc.dr.sc. Dijana Drandić, mag.prim.educ., e-mail: dijana.drandic@ymail.com

2 Izv.prof.dr.sc. Mirjana Radetić-Paić, defektolog-socijalni pedagog, e-mail: miradet@unipu.hr 
suradnji na sudionicima s obzirom na dvije sociodemografske varijable: radionice/seminari o radu s djecom/učenicima s teškoćama i stupanj obrazovanja pomoćnika u nastavi. Svakako je važno naglasiti međusobnu suradnju i podržavajući odnos pomoćnika u nastavi $i$ učitelja u razredu kako bi zajedničkim radom osigurali dostatne psihološke, pedagoške, programsko-organizacijske, didaktičko-metodičke i socijalne mogućnosti inkluzivnog djelovanja škole. Poseban doprinos ovog istraživanja ogleda se u znanstvenom saznanju da inkluzivno obrazovanje doprinosi razvoju inkluzivnih vrijednosti i prihvaćanju različitosti kod svih učenika, ali i unaprjeđenju položaja ove ranjive skupine kroz promjene u pristupu samom obrazovanju.

\section{UVOD}

Djeca (učenici) s teškoćama dugo vremena su bila marginalizirana, posebno zbog neodgovarajućih organizacijskih i materijalnih uvjeta, nedostatka odgovarajućih stručnih suradnika te velikog broja djece u razrednim odjeljenjima. Za Bouillet (2010.), djeca s teškoćama u razvoju su ona koja pokazuju određena razvojna odstupanja i koja zbog toga trebaju dodatnu potporu i primjeren program školovanja i prilagodbe u nastavi, u cilju stvaranja kreativnog i poticajnog okruženja za njihovo uključivanje u redovno školovanje. To podrazumijeva identificiranje posebnih potreba, prilagodbu didaktičko-metodičkog rada, suradnju s relevantnim institucijama, stručnjacima i drugim sudionicima inkluzivnog odgoja i obrazovanja. Tek 70-ih godina prošlog stoljeća u odgojno-obrazovnim sustavima već razvijenih zemalja započelo se s postupnim smanjenjem broja specijalnih škola, ustanova i odvojenog obrazovanja u cilju povećanja broja djece s teškoćama u redovnim školama. Promjene i prilagodbe onima koji su "različiti" potaknulo je i pitanje prava na njihovo obrazovanje. Važno je naglasiti da je najveći utjecaj na određivanje koncepta i provođenja obrazovne inkluzije djece/učenika s teškoćama, na međunarodnoj razini imala dva dokumenta: Izjava iz Salamanke i Okvir za djelovanje o obrazovanju za posebne potrebe (The Salamanca Statement and Framework for Action on Special Needs Education, UNESCO, 1994.), kojima se promiče pravo svakog djeteta da, bez obzira na bilo kakve razlike, bude uključeno u obrazovni sustav redovnih škola. Takvo obrazovanje pretpostavlja svakodnevno "sudjelovanje u školi" u skladu s njihovim sposobnostima te osiguranje uvjeta za usvajanje znanja i vještina kako bi stekli samostalnost i socijalnu uključenost (Miles, 2000.). Inkluzivno obrazovanje prije svega traži suradnju između redovnog obrazovanja i obrazovanja za posebne potrebe kako bi se osigurao i razradio sustav podrške koji će odgovarati odgojno-obrazovnim potrebama učenika s teškoćama.

Kako je Hrvatska potpisnica važnih međunarodnih dokumenata kojima se regulira i osigurava pravo na obrazovanje, dužnost države je svakom djetetu stvoriti optimalne uvjete i osigurati kvalitetno obrazovanje. Igrić (2015.a) odbacuje praksu specijalnog obrazovanja djece s teškoćama i usmjerava pažnju na povećanje svijesti društva o 
njihovoj diskriminaciji u obrazovanju te na njihovo uključivanje u obrazovanje zajedno s ostalim vršnjacima uz naglašen pozitivan utjecaj i na ostale učenike u razredu. U našem odgojno-obrazovnom sustavu inkluzija učenika s teškoćama uvedena je u zakonske propise početkom 80-ih godina prošlog stoljeća, donošenjem Zakona o odgoju i osnovnom obrazovanju u SR Hrvatskoj (1980.), kojim se uvodi mogućnost redovnog školovanja djece s teškoćama s djecom bez teškoća. Obrazovna inkluzija u svojim temeljima proširuje i produbljuje obrazovni model integracije djece s teškoćama u razvoju u redovno školovanje, pa kao takva mora biti dio nacionalnih kurikuluma, obrazovne i socijalne politike, i predstavlja jedan od najvažnijih aspekata društvene inkluzije, tj. društvene jednakosti i prihvatljivosti. Jer takvo "prošireno obrazovanje" koje uzima u obzir obrazovne zahtjeve sve djece (s posebnom usmjerenošću na onu djecu koja su podložna socijalnoj isključivosti i izloženi su socijalnoj marginalizaciji), smanjuje diskriminaciju, ranjivost i obespravljenost takvih skupina u društvu (Karamatić Brčić, 2011.). Uključivanje u sustav redovnih škola predstavlja široku i značajnu društvenu vrijednost koja se, tvrdi Booth (2000.), kada se primjenjuje na inkluzivno obrazovanje, opisuje kao proces trajne socijalizacije kroz povećanje sudjelovanja učenika s teškoćama u kulturama, kurikulumima i zajednicama redovnih škola. Stoga je, objašnjava Drandić (2017.), temeljno načelo inkluzivnog obrazovanja međusobna suradnja i podrška prema kojoj svi učenici u razredu zajedno uče, bez obzira na bilo koju različitost ili sposobnost koju posjeduju. Inkluzivni odgoj i obrazovanje, prema Drandić i Lazarić (2018.: 22), uključuje mnogobrojne pristupe i metode, a posebice:

- različite odgojno-obrazovne potrebe učenika

- prilagodbu odgojno-obrazovnih ishoda

- prilagodbu pristupa učenja i poučavanja

- prilagodbu metoda i strategija

- prilagodbu vrednovanja učeničkih postignuća

- podršku stručnog tima

- osposobljavanje i uključivanje pomoćnika u nastavi te

- međusobnu interakciji i inkluziju različitosti na razini odgojno-obrazovne prakse cjelokupne zajednice kojoj učenik s teškoćama pripada.

Kvaliteta inkluzivnog obrazovnog učenika s različitim teškoćama u razvoju u redovnim školama značajno ovisi o učiteljima koji se sve više suočavaju s izazovima organiziranja i izvođenja nastave prilagođene takvim učenicima. Učitelji su u redovnim školama direktni nositelji edukacijskog uključivanja (inkluzije) i njihovi pozitivni stavovi prema inkluzivnom obrazovanju i stručnom usavršavanje uvelike utječu na njihovo zalaganje i kvalitetno poučavanje učenika s poteškoćama (Skočić Mihić,Vlah i Šokić, 2018.). Da bi učitelji mogli uspješno provoditi obrazovnu inkluziju u redovnoj školi, potrebna im je podrška, kako organizacijska tako i stručna. Igrić (2015.b) ističe spori razvoj inkluzivne škole u Hrvatskoj i potrebu usvajanja najučinkovitije metode 
rada s djecom s teškoćama. Isto tako, roditelji djece s teškoćama i stručni suradnici (pedagozi, psiholozi, socijalni pedagozi, edukacijski rehabilitatori) uočili su mogućnost i potrebu angažiranja pomoćnika u nastavi prema uzoru na druge prakse (Chopra i French, 2004.; Werts i sur., 2004.; Suter i Giangreco, 2009.). Cilj takve podrške jest prije svega u pružanju pomoći učeniku s teškoćama, ali i učitelju. Model inkluzivnog obrazovanja za koji se odlučila provesti naša država odnosi se na uključivanje pomoćnika u nastavi. Napokon, 2018. godine donesen je i Pravilnik o pomoćnicima u nastavi i stručnim komunikacijskim posrednicima (NN, 102/2018.), kojim se definiraju načini uključivanja te način i sadržaj osposobljavanja i obavljanja poslova pomoćnika u nastavi i stručnih komunikacijskih posrednika u školama i drugim javnim ustanovama koje provode djelatnost odgoja i obrazovanja. Zato je bilo važno istražiti suradnički odnos pomoćnika u nastavi i učitelja kroz inkluzivni koncept, odnosno koncept odgoja i obrazovanje za sve, a koji se razlikuje od modela integracije - što će više biti naglašeno u nastavku.

Škole uvođenjem pomoćnika u nastavi kao modela podrške moraju prepoznati i odgovoriti na različite potrebe svojih učenika te osigurati njihovo kvalitetno obrazovanje. Primarna uloga pomoćnika u nastavi jest da budu podrška učeniku s teškoćama u njegovim svakodnevnim aktivnostima te da budu spremni na dodatan angažman i učenje, da u razredu i školi potiču prihvaćanje i razumijevanje individualnih razlika, da stvaraju prilike za učenje o razlikama, samopoštovanju, osjećaju pripadnosti školskoj zajednici. Pomoćnik u nastavi ima ulogu i, između ostalog, podrške učitelju, školi, kurikulumu, roditeljima ali i ostalim učenicima u razredu. U literaturi se navode mnogobrojni poslovi odnosno područja rada pomoćnika u nastavi (Pickett, 1999.; Greenspan i Wieder, 2003.; Igrić i Fuček, 2012.; Wagner Jakab i sur., 2016.; Puškarić i sur., 2017.; Drandić, 2017.; Pravilnik o pomoćnicima u nastavi i stručnim komunikacijskim posrednicima, 2018.), a najčešće se odnose na podršku u pripremi organizacije i realizacije nastavnog procesa, podršku djetetu/učeniku u školskom okruženju, suradnju sa stručnjacima, roditeljima učenika s teškoćama u razvoju, praćenje i dokumentiranje napredovanja djeteta te uspostavljanje interakcije s ostalim (tipičnim) učenicima i izgrađivanje pozitivnog emocionalno-socijalnog ozračja u razredu. Dakle, pomoćnik u nastavi je podrška i učitelju, a kako tvrde autorice Bentham i Hutchins, (2006.), zajedno s učiteljem djeluje kao "most" između učenika i kurikuluma.

U tom kontekstu, postavlja se pitanje koje su zapravo odrednice suradnje pomoćnika u nastavi i učitelja? U literaturi ih pronalazimo nekoliko:

- komunikacijske vještine (Riggs i Mueller, 2001.; Morgan i sur., 2001.; Wallace i sur., 2001.; Giangreco i sur., 2001.; Giangreco i sur., 2010.)

- kolegijalnost te jasne uloge i očekivanja koje čine profesionalnost (Thompson, 2002.; Pickett i Gerlach, 2003.; Brand, 2004.; Igrić, 2015.a) 
- pristup i stav ravnatelja škole edukacijskom uključivanju i socijalizaciji (Daniels i McBride, 2001.; Brand, 2004.)

- metodičko-didaktički aspekti rada te kompetentnost za rad s djecom s teškoćama u razvoju (Pickett, i Gerlach, 2003.; Logan, 2006.; Blatchford i sur., 2011.; Jones i sur., 2012.; Radetić-Paić, 2015.; Igrić, 2015.b; Gerlach, 2016.).

Također, autori pojedinih inozemnih istraživanja govore u prilog značajnijeg uključivanja pomoćnika u nastavi za sve učenike u razredu, a ne samo za učenike $s$ teškoćama (Cremin i sur., 2005.; Schlapp i sur., 2003.; Mistry i sur., 2004.; Angelides i sur.; Takala, 2007.; Giangreco, 2009.). Navedeno potvrđuje i istraživanje Devecchi i Rouse (2010.) koji ističu da je pomoćnik u nastavi podrška svim učenicima s ciljem da svi oni budu usmjereni na izvršavanje zadataka, da se ponašaju u skladu s pravilima, da se međusobno pomažu i prihvaćaju kao razredni kolektiv. Provođenje inkluzivnog obrazovanja polazi od poštovanja prava djece/učenika s teškoćama te njihovih razvojnih i obrazovnih mogućnosti, kako bi ih kroz kvalitetan i primjeren odgoj i obrazovanje osposobili za samostalan život. Svakako je važno za istaknuti međusobnu suradnju i podržavajući odnos pomoćnika u nastavi i učitelja u razredu. Dobrobit za sve učenike ogleda se stoga kroz izgradnju pedagoške, didaktičko-metodičke i socijalne mogućnosti inkluzivnog djelovanja škole kao zajednice različitih (Ivančić i Stančić, 2013.).

\section{PROBLEM I PREDMET ISTRAŽIVANJA}

Inkluzija podrazumijeva, ne samo uključivanje djeteta s teškoćama u razvoju u redovito školovanje, nego i osiguranje materijalnih, kadrovskih i tehničkih uvjeta kako bi dijete (učenik) s teškoćama sudjelovalo u redovitom školovanju na način da se poštuje njegova različitost i posebnost. $U$ tom kontekstu, do posebnog izražaja dolazi savladavanje prepreka u učenju i aktivno sudjelovanje učenika s teškoćama u razvoju u nastavi i različitost koju treba shvatiti kao potrebu za potporom u učenju i sudjelovanje u obrazovno-odgojnom procesu, a ne problem koji treba premostiti. Bilo da se radi o individualiziranom ili prilagođenom programu prema kojemu se učenik $s$ teškoćama školuje, pomoćnik u nastavi kontinuirano surađuje s učiteljem u razredu, dogovara razinu i oblik pomoći učeniku s teškoćama kao posebno ranjivoj skupini djece i daje povratnu informaciju učitelju, može biti uključen u provođenje različitih aktivnosti i s ostalim učenicima u razredu. Imajući u vidu značaj uloge pomoćnika u nastavi u procesu odgojno-obrazovne inkluzije te uvažavajući činjenicu da će velika većina učitelja biti u situaciji da u odgojno-obrazovnom procesu radi s učenicima s različitim teškoćama, ovaj je rad usmjeren analizi stavova prema kojima pomoćnici u nastavi procjenjuju međusobnu suradnju s učiteljima u inkluzivnom razredu. 


\section{CILJ ISTRAŽIVANJA}

Polazeći od činjenice da pomoćnici u nastavi i učitelji kroz međusobnu suradnju preuzimaju obavezu i odgovornost provođenja obrazovne inkluzije učenika s teškoćama u razvoju u sigurnom i poticajnom okruženju razredne zajednice, poštujući mogućnosti i različitosti svakog učenika, ovaj rad usmjeren je analizi stavova prema kojima pomoćnici u nastavi procjenjuju suradnju s učiteljima u inkluzivnim školama. Njihovo mišljenje o suradničkoj podršci ima poseban značaj za razumijevanje inkluzivnog procesa. Problemi s kojima su suočeni pomoćnici u nastavi i učitelji u provođenju odgojno-obrazovne inkluzije, a koji polaze od nedovoljnog znanja i stručnosti do predrasuda i neprilagođenih nastavnih planova i programa, usmjeravaju ih na međusobnu suradnju i zajednički rad. U vezi s tim i sam koncept inkluzivnog obrazovanja naglašava podršku učeniku s teškoćama, planiranje i izvođenje zajedničkih aktivnosti u razredu, kompetencije za rad s učenicima s teškoćama, suradnju s roditeljima te stavove i procjene korištenja različitih metoda i postupaka prilagodbe programa učeniku s teškoćama, kao i izgradnju pozitivnog razrednog ozračja za sve učenike. Cilj je ovog istraživanja bio dobiti uvid u suradnički rad pomoćnika u nastavi i učitelja te iz perspektive pomoćnika u nastavi istražiti njihove stavove o međusobnoj suradnj u provođenju odgojno-obrazovne inkluzije učenika s teškoćama u redovne razrede, zatim ispitati povezanost stavova pomoćnika u nastavi s njihovim sociodemografskim obilježjima: spol (muški, ženski), godine života (do 30 godina, do 40 godina, iznad 40 godina), stupanj obrazovanja (srednja škola, preddiplomski studij, diplomski studij), podrška sam učeniku koji pohađa (osnovnu školu od 1. do 4. razreda, osnovnu školu od 5. do 8. razreda, srednju školu), osim edukacije u ovom projektu, završio/la sam druge radionice/seminare o radu s djecom/učenicima s teškoćama (da, ne), radno iskustvo kao pomoćnik u nastavi (do 1 godine, do 2 godine, 3 i više godina).

\section{METODA}

Slijedom navedenog cilja, u ovom istraživanju postavljena su sljedeća istraživačka pitanja:

1. Kako pomoćnici u nastavi procjenjuju suradnju s učiteljem u provođenju odgojno-obrazovne inkluzije učenika s teškoćama?

2. Koja su to sociodemografska obilježja pomoćnika u nastavi (spol, godine života, stupanj obrazovanja, razred koji učenik pohađa, radionice/seminari, radno iskustvo) koja utječu na spremnost na međusobnu suradnju i uključivanje u odgojno-obrazovni proces?

3. Što bi valjalo promijeniti u cilju osiguranja podrške i međusobne suradnje pomoćnika u nastavi i učitelja? 


\section{Prikupljanje podataka i uzorak istraživanja}

Istraživanje je provedeno na uzorku pomoćnika u nastavi u radu s učenicima s teškoćama koji su bili u vrijeme istraživanja zaposleni u osnovnim i srednjim školama u Istarskoj županiji. Istraživanje je obuhvatilo 170 pomoćnika u nastavi od kojih je većina ženskog spola (88\%). Prema dobi, gotovo je podjednako pomoćnika do 30 godina života (32\%) i od 31 do 40 (33\%), dok ih nešto više ima iznad 40 godina života (35\%). U odnosu na stupanj obrazovanja, $42 \%$ ima završenu srednju školu, $24 \%$ preddiplomski, a $34 \%$ diplomski studij. Prema podršci učeniku s obzirom na razred koji pohađa, najviše pomoćnika u nastavi radi u osnovnoj školi i to: $44 \%$ podrška je učenicima koji pohađaju nastavu od 1 . do 4 . razreda, $48 \%$ podrška je učenicima viših razreda osnovne škole, dok ih je svega $8 \%$ angažirano u srednjoj školi. Najveći broj ispitanika (65\%) nakon završene obvezne edukacije za pomoćnika u nastavi nije sudjelovalo u dodatnim radionicama/seminarima o radu s djecom/učenicima s teškoćama. Sukladno tome, $23 \%$ ispitanika ima do jedne godine radnog iskustva kao pomoćnik u nastavi, $45 \%$ do dvije godine, a njih $32 \%$ ima tri i više godina iskustva.

Podaci o stavovima pomoćnika u nastavi prema suradnji s učiteljima u razredu prikupljeni su podjelom upitnika pomoćnicima u nastavi koji su sudjelovali na panel raspravi organiziranoj u svibnju 2018. u sklopu projekta Mozaik 3, Istarske županije s ciljem što boljeg informiranja i osposobljavanja pomoćnika u nastavi kao ključnih osoba u provođenju inkluzivnog obrazovanja učenika s teškoćama u redovne škole uz prilagođene odgojno-obrazovne programe. Stoga, s obzirom na primarni cilj rada, ovakav uzorak ispitanika te način prikupljanja podataka je odgovarajuć i prikladan je za potrebe istraživanja. Prije provođenja istraživanja, sudionici su upoznati s ciljem samog istraživanja, objašnjen je postupak provođenja istraživanja, povjerljivost podataka te anonimnost njihovog sudjelovanja ${ }^{3}$.

\section{Istraživački instrument}

Pregledom dosadašnjih istraživanja inkluzije djece/učenika s teškoćama u redovne škole, u našem odgojno-obrazovnom sustavu nije pronađen odgovarajući instrument te je za potrebe ovog istraživanja posebno konstruirana Skala stavova prema suradnji pomoćnika u nastavi i učitelja PUN-učitelji. Prva verzija skale sastojala se od 28 čestica koje obuhvaćaju razne aspekte suradnje i rada učitelja i pomoćnika u nastavi u odgojno-obrazovnom procesu redovnih škola u koji su uključeni i učenici

3 Istraživanje je odobreno odlukom Povjerenstva za procjenu etičnosti istraživanja Fakulteta za odgojne i obrazovne znanosti Sveučilišta Jurja Dobrile u Puli.

4 PUN označava izraz "pomoćnik u nastavi". 
s teškoćama. U postupku testiranja i prilagodbe skale isključene su 4 čestice. Naime, analize koje smo dobili ukazale su da te čestice imaju lošije psihometrijske karakteristike te su izostavljene iz daljnjeg istraživanja. Finalna verzija Skale PUN-učitelj mjeri suradnju pomoćnika u nastavi i učitelja kroz 24 tvrdnje kojima je priložena peterostupanjska skala procjene Likertova tipa: 1 = nimalo se ne slažem, 2 = ne slažem se, 3 = niti se slažem/niti se ne slažem, 4 = slažem se, 5 = potpuno se slažem. Sudionici su ispunjavali i upitnik sa 6 sociodemografskih obilježja: spol (muški, ženski), godine života (do 30 godina, do 40 godina, iznad 40 godina), stupanj obrazovanja (srednja škola, preddiplomski studij, diplomski studij), podrška sam učeniku koji pohađa (osnovnu školu od 1. do 4. razreda, osnovnu školu od 5. do 8. razreda, srednju školu), osim edukacije u ovom projektu, završio/la sam druge radionice/seminare o radu s djecom/učenicima s teškoćama (da, ne), radno iskustvo kao pomoćnik u nastavi (do 1 godine, do 2 godine, 3 i više godina).

Obrada podataka dobivenih istraživanjem obavljena je osnovnom deskriptivnom statistikom, a na varijablama, priređenim za statističku obradu, obavljene su sljedeće analize i postupci: utvrđivanje distribucije odgovora koristeći njihove frekvencije; hijerarhijska faktorska analiza pod komponentnim modelom, do broja utvrđenog Kaiser-Meyer-Olkinovim (KMO) kriterijem i primjenom varimax rotacije, t-test nezavisnih uzoraka te jednofaktorska analiza varijance - ANOVA (uzevši u obzir broj kategorija ispitanika).

\section{REZULTATI I RASPRAVA}

Od ukupno 24 tvrdnje za koje su pomoćnici u nastavi procjenjivali stupanj u kojem se s njima slažu, kod velike većine tvrdnji ustanovljena je vrlo visoka podudarnost među pomoćnicima u nastavi, budući da se s njih 19 složilo, kod 4 tvrdnje postigli su manji stupanj slaganja, dok je kod jedne tvrdnje $1 / 3$ ispitanika izrazila neslaganje (Tablica 1.). Frekvencija odgovora pomoćnika u nastavi ukazuje da njih preko $72 \%$ smatra prema njihovom dosadašnjem iskustvu u radu s djecom s teškoćama u redovnoj školi da zajednički rad pomoćnika u nastavi i učitelja pozitivno utječe na obrazovna postignuća i ponašanje svih učenika (tvrdnja 24/Iz mog dosadašnjeg iskustva smatram da naš zajednički rad u razredu pozitivno utječe na obrazovna postignuća i ponašanje svih učenika.). Također, više od $70 \%$ ispitanika slaže se da suradnja pomoćnika u nastavi i učitelja olakšava provođenje nastavnog plana i programa, a da pri tome uvažavanje iskustva učitelja svakako doprinosi boljoj prilagodbi metoda i postupaka u zajedničkom radu (tvrdnje 22/Uvažavam iskustva učitelja/nastavnika u neposrednom radu s učenicima s teškoćama. i 23/Smatram da suradnja nas PUN i učitelja u razredu olakšava provođenje nastavnog plana i programa.). Istodobno, preko 75\% 
ispitanika ističe da učenik $s$ teškoćama bolje napreduje kada je prisutna suradnja učitelja i pomoćnika u nastavi (tvrdnja 15/Smatram da suradnja nas PUN i učitelja u razredu olakšava provođenje nastavnog plana i programa., što se može povezati s tvrdnjom broj 2/Smatram da je suradnja nas PUN i učitelja poticaj ostalim učenicima da prihvate učenika s teškoćama kao ravnopravnog člana razredne zajednice., koja tu suradnju opisuje kroz poticaj ostalim učenicima da prihvate učenika s teškoćama kao ravnopravnog člana razredne zajednice. Distribucija odgovora na tvrdnju 11/ Naš zajednički rad pridonio je kvalitetnijoj nastavi. pokazuje upravo doprinos takvog zajedničkog rada kvalitetnijoj nastavi, oslobođenoj bilo kakvih barijera ili predrasuda prema različitostima, mogućnostima i sposobnostima učenika u razredu. Ohrabrujuć je podatak da među ispitanicima prevladava izrazito pozitivan stav o tome da uspješna odgojno-obrazovna inkluzija učenika s teškoćama u redovne škole uz podršku i uključivanje pomoćnika u nastavi podrazumijeva i međusobnu suradnju svih uključenih u ovaj proces, a posebno je pri tome naglasak na suradnji i međusobnoj podršci pomoćnika u nastavi i učitelja, a sve u cilju osiguranja uvjeta za kvalitetnije obrazovanje, prilagođene nastavne metode i postupke i bolju socijalizaciju posebno ranjivih skupina u koje ubrajamo i djecu/učenike s teškoćama. Istaknuta je visoka razina slaganja s procjenama vlastitog obrazovanja, educiranosti i pripremljenosti. Naime, preko $30 \%$ ispitanika ne smatra se dovoljno kompetentnima da mogu provoditi individualizirane odgojno-obrazovne programe za učenike s teškoćama, samostalno bez pomoći učitelja. U tom je smislu opravdano očekivati da će se pomoćnici u nastavi oslanjati na iskustva i kompetencije učitelja u neposrednom radu s učenicima s teškoćama. 
Tablica 1. Raspodjela odgovora pomoćnika u nastavi prema stupnju slaganja s ponuđenim tvrdnjama na Skali PUN-učitelj

\begin{tabular}{|c|c|c|c|c|c|}
\hline Tvrdnja & $\begin{array}{l}\text { Nimalo se } \\
\text { ne slažem } \\
\%\end{array}$ & $\begin{array}{l}\text { Ne slažem se } \\
\%\end{array}$ & $\begin{array}{l}\text { Neodlučan } \\
\%\end{array}$ & $\begin{array}{l}\text { Slažem } \\
\text { se } \\
\%\end{array}$ & $\begin{array}{l}\text { Potpuno } \\
\text { se slažem } \\
\%\end{array}$ \\
\hline $\begin{array}{l}\text { 1. Na početku školske godine učitelj } \\
\text { me je upoznao s dosadašnjim } \\
\text { postignućima učenika s teškoćama } \\
\text { kojemu sam dodijeljen/a. }\end{array}$ & 7,10 & 10,60 & 8,20 & 38,80 & 35,30 \\
\hline $\begin{array}{l}\text { 2. Smatram da je suradnja nas PUN } \\
\text { i učitelja poticaj ostalim učenicima } \\
\text { da prihvate učenika s teškoćama kao } \\
\text { ravnopravnog člana razredne zajednice. }\end{array}$ & 1,20 & 0,00 & 5,90 & 31,80 & 61,20 \\
\hline $\begin{array}{l}\text { 3. U suradnji s učiteljem/nastavnikom } \\
\text { zajednički planiramo izvannastavne } \\
\text { aktivnosti na kojima sudjeluje učenik s } \\
\text { teškoćama. }\end{array}$ & 4,70 & 14,10 & 11,80 & 30,60 & 38,80 \\
\hline $\begin{array}{l}\text { 4. Zajedno dogovaramo uključivanje } \\
\text { učenika s teškoćama u svakodnevne } \\
\text { aktivnosti u razredu. }\end{array}$ & 2,40 & 3,50 & 9,40 & 40,00 & 44,70 \\
\hline $\begin{array}{l}\text { 5. Učitelj mi pomaže i daje sugestije } \\
\text { u prilagodbi metoda i postupaka } \\
\text { primjerenih učeniku s teškoćama. }\end{array}$ & 0,00 & 7,10 & 17,60 & 34,10 & 41,20 \\
\hline $\begin{array}{l}\text { 6. Učitelj me upozorava na pogreške u } \\
\text { mojem radu. }\end{array}$ & 8,20 & 15,30 & 15,30 & 37,60 & 23,50 \\
\hline $\begin{array}{l}\text { 7. Učitelj me upućuje na stručnu službu } \\
\text { škole ukoliko zajedno ne dođemo } \\
\text { do najboljeg rješenja za učenika s } \\
\text { teškoćama. }\end{array}$ & 4,70 & 9,40 & 11,80 & 37,60 & 36,50 \\
\hline $\begin{array}{l}\text { 8. Radionice o međusobnoj suradnji } \\
\text { nas PUN i učitelja pomogle bi boljem } \\
\text { razumijevanju uloge PUN u razredu. }\end{array}$ & 0,00 & 0,00 & 7,00 & 36,50 & 56,50 \\
\hline $\begin{array}{l}\text { 9. Učitelj podržava moj angažman i } \\
\text { kod ostalih učenika u razredu kojima } \\
\text { je potrebna pomoć u savladavanju } \\
\text { nastavnog gradiva. }\end{array}$ & 4,70 & 10,6 & 8,20 & 30,60 & 45,90 \\
\hline $\begin{array}{l}\text { 10. Prema uputama učitelja } \\
\text { kontaktiram s roditeljima i } \\
\text { obavještavam ih o napretku ili } \\
\text { zaostajanju učenika s teškoćama. }\end{array}$ & 3,50 & 7,10 & 9,40 & 31,80 & 48,20 \\
\hline $\begin{array}{l}\text { 11. Naš zajednički rad pridonio je } \\
\text { kvalitetnijoj nastavi. }\end{array}$ & 0,00 & 2,40 & 4,70 & 35,30 & 57,60 \\
\hline
\end{tabular}


12. Uključivanjem nas PUN učitelj ima više vremena za druge učenike u 1,20 2,40 3,50 17,60 75,30 razredu.

13. Zajedno dogovaramo načine i oblike rada temeljene na preporukama stručnih suradnika škole, vodeći računa o specifičnostima u nastavnom procesu $\begin{array}{lllll}1,20 & 4,70 \quad 5,90 & 45,90 & 42,40\end{array}$ i sposobnostima učenika s teškoćama.

14. U svakodnevnom radu zajednički kreiramo ozračje za poticanje aktivnosti svih učenika u razredu.

15. Smatram da suradnja nas PUN i učitelja u razredu olakšava provođenje nastavnog plana i programa.

16. Smatram da je potrebno organizirati još dodatnih edukacija učiteljima kako bi stekli kompetencije 0,00 1,20 $7,10 \quad 30,60$ 61,20 za rad i suradnju s PUN.

17. Uspješno surađujem s učiteljem u razredu.

1,20

0,00

9,40

23,50

65,90

18. Smatram da sam dovoljno educiran za suradnju s učiteljem u razredu.

2,40

10,60

22,40

30,60 34,00

19. Smatram se dovoljno kompetentnim da mogu provoditi individualizirane odgojno-obrazovne programe za učenike s teškoćama samostalno bez pomoći učitelja.

20. Zadovoljan sam podrškom koju mi pruža učitelj u mojoj odgojnoobrazovnoj ustanovi.

21. U suradnji s učiteljem planiram oblike i metode provođena prilagođenog programa.

$\begin{array}{lllll}8,20 & 23,50 & 30,60 & 22,40 & 15,30\end{array}$

22. Uvažavam iskustva učitelja/ nastavnika u neposrednom radu s učenicima s teškoćama.

23. Smatram da suradnja nas PUN i učitelja u razredu olakšava provođenje nastavnog plana i programa.

24. Iz mog dosadašnjeg iskustva smatram da naš zajednički rad u razredu pozitivno utječe na obrazovna 0,00 4,70 0,00 3,60 12,90 32,90 50,60 postignuća i ponašanje svih učenika.

1,20

8,20

25,90

64,70 
U nastavku su prikazane izračunate aritmetičke sredine odgovora na cijelom uzorku ispitanika ( $N=170$ ) za sve 24 tvrdnje. Budući da su pomoćnici u nastavi stupnjevali stavove koji mjere suradnju s učiteljima na skali od 1 (nimalo se ne slažem) do 5 (potpuno se slažem), rezultate koje smo dobili nalaze se u rasponu od 3,13 do 4,75. Iz podataka prikazanim u Tablici 2. možemo zaključiti da se u okviru dobivenih rezultata uočavaju razlike u rasponima između utvrđenih srednjih vrijednosti. Vidljivo je da su pomoćnici u nastavi najveće slaganje $(\mathrm{M}=4,75 ; \mathrm{SD}=0,43)$ pokazali s tvrdnjom 15/Smatram da učenik s teškoćama bolje napreduje kada je prisutna suradnja učitelja i pomoćnika u nastavi. Zatim ističu tvrdnju 23/Smatram da suradnja nas pomoćnika u nastavi i učitelja u razredu olakšava provođenje planiranog nastavnog plana i programa., $\mathrm{M}=4,68$ (SD = 0,51) i tvrdnju 24/Iz mog dosadašnjeg iskustva smatram da naš zajednički rad u razredu pozitivno utječe na obrazovna postignuća i ponašanje ostalih učenika ( $M=4,68 ; S D=0,55)$. S druge strane, najmanje slaganje pomoćnici u nastavi pokazali su prema tvrdnji 19/Smatram se dovoljno kompetentnim da mogu provoditi individualizirane odgojno-obrazovne programe za učenike s teškoćama samostalno bez pomoći učitelja., ( $\mathrm{M}=3,13$; SD = 1,18), tvrdnji 18/Smatram da sam dovoljno educiran za suradnju s učiteljem. $(M=3,84 ; S D=1,08)$ i tvrdnji $6 /$ Učitelj me upozorava na moje pogreške u radu. $(M=3,53$; $S D=1,23)$, jer su dobiveni rezultat na skali međusobne suradnje u prosjeku najniži.

Dobiveni rezultati navode nas na zaključak da su ispitanici najviše rangirali tvrdnje koje opisuju prednosti koje se ostvaruju zajedničkim radom i suradnjom te dobrobit koje donosi uključivanje pomoćnika u nastavi kao podrške učeniku s teškoćama. Temeljne karakteristike i vrijednosti odgojno-obrazovne inkluzije učenika s teškoćama u redovnu školu odnose se prije svega na osiguranje uvjeta za timski rad svih sudionika zasnovan na međusobnom povjerenju, usmjeren na pronalaženju adekvatnog načina podrške ovom procesu, socijalizaciji učenika s teškoćama te stvaranje pozitivnog razrednog ozračja i kvalitetnijeg obrazovanja. Dok se rezultati koji su u prosjeku nešto niži odnose na tvrdnje koje opisuju osposobljenost i kompetencije pomoćnika u nastavi u provođenju individualiziranih odgojno-obrazovnih programa i svakodnevnih aktivnosti podrške učeniku s teškoćama. 
Tablica 2. Deskriptivni pokazatelji dobivenih rezultata na Skali PUN-učitelj (N=170)

Tvrdnja

Min. Max. M SD

1. Na početku školske godine učitelj me je upoznao s dosadašnjim postignućima učenika s teškoćama kojemu sam dodijeljen/a.

$1 \quad 5 \quad 3,85 \quad 1,21$

2. Smatram da je suradnja nas PUN i učitelja poticaj ostalim učenicima da prihvate učenika s teškoćama kao ravnopravnog člana razredne zajednice.

$\begin{array}{llll}2 & 5 & 4,53 & 0,66\end{array}$

3. U suradnji s učiteljem/nastavnikom zajednički planiramo izvannastavne aktivnosti na kojima sudjeluje učenik s teškoćama.

$1 \quad 5 \quad 3,85 \quad 1,21$

4. Zajedno dogovaramo uključivanje učenika s teškoćama u svakodnevne aktivnosti u razredu.

$\begin{array}{llll}1 & 5 & 4,21 & 0,92\end{array}$

5. Učitelj mi pomaže i daje sugestije u prilagodbi metoda i postupaka primjerenih učeniku s teškoćama.

$2 \quad 5 \quad 4,09 \quad 0,93$

6. Učitelj me upozorava na pogreške u mojem radu.

$1 \quad 5 \quad 3,53 \quad 1,23$

7. Učitelj me upućuje na stručnu službu škole ukoliko zajedno ne dođemo do najboljeg rješenja za učenika s teškoćama.

$1 \quad 5 \quad 3,92 \quad 1,13$

8. Radionice o međusobnoj suradnji nas PUN i učitelja pomogle bi boljem razumijevanju uloge PUN u razredu.

$\begin{array}{llll}3 & 5 & 4,49 & 0,62\end{array}$

9. Učitelj podržava moj angažman i kod ostalih učenika u razredu kojima je potrebna pomoć u savladavanju nastavnog gradiva.

$1 \quad 5 \quad 4,02 \quad 1,18$

10. Prema uputama učitelja kontaktiram s roditeljima i obavještavam ih o napretku ili zaostajanju učenika s teškoćama.

$\begin{array}{llll}1 & 5 & 4,14 & 1,07\end{array}$
11. Naš zajednički rad pridonio je kvalitetnijoj nastavi.

$2 \quad 5 \quad 4,48 \quad 0,69$

12. Uključivanjem nas PUN učitelj ima više vremena za druge učenike u razredu.

$1 \quad 5 \quad 4,64 \quad 0,76$

13. Zajedno dogovaramo načine i oblike rada temeljene na preporukama $\begin{array}{lllll}\text { stručnih suradnika škole, vodeći računa o specifičnostima u nastavnom } & 1 & 5 & 4,24 & 0,85\end{array}$ procesu i sposobnostima učenika s teškoćama.

14. U svakodnevnom radu zajednički kreiramo ozračje za poticanje aktivnosti svih učenika u razredu.

$1 \quad 5 \quad 3,91 \quad 1,06$


15. Smatram da učenik s teškoćama bolje napreduje kada je prisutna suradnja učitelja s PUN.

$4 \quad 5 \quad 4,75 \quad 0,43$

16. Smatram da je potrebno organizirati još dodatnih edukacija učiteljima kako bi stekli kompetencije za rad i suradnju s PUN.

$2 \quad 5 \quad 4,52 \quad 0,68$

17. Uspješno surađujem s učiteljem u razredu.

$1 \quad 5 \quad 4,53 \quad 0,76$

18. Smatram da sam dovoljno educiran za suradnju s učiteljem u razredu. $\quad \begin{array}{llll}1 & 5 & 3,84 & \text { 1,08 }\end{array}$

19. Smatram se dovoljno kompetentnim da mogu provoditi

individualizirane odgojno-obrazovne programe za učenike s teškoćama $\quad \begin{array}{llll}1 & 5 & 3,13 & 1,18\end{array}$ samostalno bez pomoći učitelja.

20. Zadovoljan sam podrškom koju mi pruža učitelj u mojoj odgojnoobrazovnoj ustanovi.

$2 \quad 5 \quad 4,31 \quad 0,82$

21. U suradnji s učiteljem planiram oblike i metode provođena prilagođenog programa.

$\begin{array}{llll}1 & 5 & 3,87 & 1,07\end{array}$

22. Uvažavam iskustva učitelja/nastavnika u neposrednom radu s učenicima s teškoćama.

$2 \quad 5 \quad 4,54 \quad 0,69$

23. Smatram da suradnja nas PUN i učitelja u razredu olakšava provođenje nastavnog plana i programa.

$\begin{array}{llll}3 & 5 & 4,68 & 0,51\end{array}$

24. Iz mog dosadašnjeg iskustva smatram da naš zajednički rad u razredu pozitivno utječe na obrazovna postignuća i ponašanje svih učenika.

$\begin{array}{llll}3 & 5 & 4,68 & 0,55\end{array}$

S obzirom na to da pomoćnici u nastavi pružaju podršku učeniku s posebnim odgojno-obrazovnim potrebama u redovnoj školi, istražili smo kako procjenjuju stavove o suradnji s učiteljima s obzirom na njihove sociodemografske varijable provjerom statističke značajnosti razlika. Kako bismo ispitali postoji li statistički značajna razlika u stavovima pomoćnika u nastavi prema suradnji s učiteljem u razredu u odnosu na spol (muški, ženski) i dodatne radionice/seminare (da,ne), t-testom nezavisnih varijabli uspoređeni su rezultati ispitivanja. Dok je jednofaktorskom analizom varijance-ANOVA istražen utjecaj godina života, stupnja obrazovanja, podrške učeniku u osnovnoj ili srednjoj školi te radnog iskustva na suradnju s učiteljem mjeren skalom PUN-učitelj. Ispitanici su prema godinama života podijeljeni u tri grupe (do 30, 31-40 i iznad 40 godina života), prema stupnju obrazovanja u tri grupe (srednja škola, preddiplomski studij i diplomski studij), prema podršci učeniku u tri grupe (učenik od 1. do 4. razreda osnovne škole, od 5. do 8. razreda osnovne škole i učenik srednje škole) i prema 
radnom iskustvu u tri grupe (do 1 godinu, do 2 godine, 3 i više godina). Iz rezultata koje smo dobili može se zaključiti da se spol, godine života, razred koji učenik pohađa i radno iskustvo nisu pokazali relevantnim nezavisnim varijablama za postojanje statistički značajnih razlika u procjeni stavova pomoćnika u nastavi prema suradnji s učiteljem u razredu. Dobiveni podatci na skali kojom se procjenjivalo pokazuju da nije utvrđena statistički značajna razlika u odgovorima sudionika istraživanja na navedenim varijablama. Prema tome, ispitanici različitog spola, godina života, razreda ili škole u kojoj su podrška učeniku s teškoćama te radnog iskustva slično, a ne statistički različito procjenjuju stavove o međusobnoj suradnji s učiteljima u inkluzivnom razredu.

Međutim, utvrđena je statistički značajna razlika u procjenjivanju stavova ispitanika kod dvije varijable: završena dodatna radionica/seminar o radu s djecom/ učenicima s teškoćama i stupanj obrazovanja (Tablica 3.).

Tablica 3. Razlike u stavovima pomoćnika u nastavi u odnosu na varijablu radionice/seminari o radu $\mathrm{s}$ djecom/učenicima s teškoćama (t-test)

\begin{tabular}{|c|c|c|c|c|}
\hline Tvrdnje & $\begin{array}{l}\text { Radionice } \\
\text { /seminari }\end{array}$ & $\mathbf{N}$ & M & SD \\
\hline \multirow{2}{*}{$\begin{array}{l}\text { 1. Na početku školske godine učitelj me je upoznao s dosadašnjim } \\
\text { postignućima učenika s teškoćama kojemu sam dodijeljen/a. }\end{array}$} & da & 56 & 3,25 & 1,33 \\
\hline & ne & 112 & 4,13 & 1,04 \\
\hline \multirow{2}{*}{$\begin{array}{l}\text { 2. Smatram da je suradnja nas PUN i učitelja poticaj ostalim učenicima } \\
\text { da prihvate učenika s teškoćama kao ravnopravnog člana razredne } \\
\text { zajednice. }\end{array}$} & da & 56 & 4,43 & 0,82 \\
\hline & ne & 112 & 4,59 & 0,56 \\
\hline \multirow{2}{*}{$\begin{array}{l}\text { 3. U suradnji s učiteljem/nastavnikom zajednički planiramo } \\
\text { izvannastavne aktivnosti na kojima sudjeluje učenik s teškoćama. }\end{array}$} & da & 56 & 3,46 & 1,46 \\
\hline & ne & 112 & 4,02 & 1,03 \\
\hline \multirow{2}{*}{$\begin{array}{l}\text { 4. Zajedno dogovaramo uključivanje učenika s teškoćama u svakodnevne } \\
\text { aktivnosti u razredu. }\end{array}$} & da & 56 & 4,00 & 1,07 \\
\hline & ne & 112 & 4,30 & 0,82 \\
\hline \multirow{2}{*}{$\begin{array}{l}\text { 5. Učitelj mi pomaže i daje sugestije u prilagodbi metoda i postupaka } \\
\text { primjerenih učeniku s teškoćama. }\end{array}$} & $\mathrm{da}$ & 56 & 3,86 & 0,92 \\
\hline & ne & 112 & 4,20 & 0,91 \\
\hline \multirow{2}{*}{ 6. Učitelj me upozorava na pogreške u mojem radu. } & da & 56 & 3,04 & 1,22 \\
\hline & ne & 112 & 3,75 & 1,17 \\
\hline \multirow{2}{*}{$\begin{array}{l}\text { 7. Učitelj me upućuje na stručnu službu škole ukoliko zajedno ne } \\
\text { dođemo do najboljeg rješenja za učenika s teškoćama. }\end{array}$} & $\mathrm{da}$ & 56 & 3,68 & 1,08 \\
\hline & ne & 112 & 4,02 & 1,14 \\
\hline \multirow{2}{*}{$\begin{array}{l}\text { 8. Radionice o međusobnoj suradnji nas PUN i učitelja pomogle bi } \\
\text { boljem razumijevanju uloge PUN u razredu. }\end{array}$} & da & 56 & 4,39 & 0,73 \\
\hline & ne & 112 & 4,54 & 0,56 \\
\hline
\end{tabular}




\begin{tabular}{|c|c|c|c|c|}
\hline \multirow{2}{*}{$\begin{array}{l}\text { 9. Učitelj podržava moj angažman i kod ostalih učenika u razredu kojima } \\
\text { je potrebna pomoć u savladavanju nastavnog gradiva. }\end{array}$} & da & 56 & 4,00 & 1,20 \\
\hline & ne & 112 & 4,02 & 1,17 \\
\hline \multirow{2}{*}{$\begin{array}{l}\text { 10. Prema uputama učitelja kontaktiram s roditeljima i obavještavam ih } \\
\text { o napretku ili zaostajanju učenika s teškoćama. }\end{array}$} & da & 56 & 4,18 & 1,11 \\
\hline & ne & 112 & 4,11 & 1,06 \\
\hline \multirow{2}{*}{ 11. Naš zajednički rad pridonio je kvalitetnijoj nastavi. } & da & 56 & 4,39 & 0,67 \\
\hline & ne & 112 & 4,52 & 0,71 \\
\hline \multirow{2}{*}{$\begin{array}{l}\text { 12. Uključivanjem nas PUN učitelj ima više vremena za druge učenike u } \\
\text { razredu. }\end{array}$} & da & 56 & 4,71 & 0,65 \\
\hline & ne & 112 & 4,59 & 0,82 \\
\hline \multirow{2}{*}{$\begin{array}{l}\text { 13. Zajedno dogovaramo načine i oblike rada temeljene na } \\
\text { preporukama stručnih suradnika škole, vodeći računa o specifičnostima } \\
\text { u nastavnom procesu i sposobnostima učenika s teškoćama. }\end{array}$} & da & 56 & 4,14 & 1,06 \\
\hline & ne & 112 & 4,27 & 0,72 \\
\hline \multirow{2}{*}{$\begin{array}{l}\text { 14. U svakodnevnom radu zajednički kreiramo ozračje za poticanje } \\
\text { aktivnosti svih učenika u razredu. }\end{array}$} & da & 56 & 3,54 & 1,12 \\
\hline & ne & 112 & 4,07 & 0,98 \\
\hline \multirow{2}{*}{$\begin{array}{l}\text { 15. Smatram da učenik s teškoćama bolje napreduje kada je prisutna } \\
\text { suradnja učitelja s PUN. }\end{array}$} & da & 56 & 4,64 & 0,48 \\
\hline & ne & 112 & 4,80 & 0,39 \\
\hline \multirow{2}{*}{$\begin{array}{l}\text { 16. Smatram da je potrebno organizirati još dodatnih edukacija } \\
\text { učiteljima kako bi stekli kompetencije za rad i suradnju s PUN. }\end{array}$} & $\mathrm{da}$ & 56 & 4,57 & 0,68 \\
\hline & ne & 112 & 4,48 & 0,68 \\
\hline \multirow{2}{*}{ 17. Uspješno surađujem s učiteljem u razredu. } & da & 56 & 4,43 & 0,91 \\
\hline & ne & 112 & 4,57 & 0,68 \\
\hline \multirow{2}{*}{$\begin{array}{l}\text { 18. Smatram da sam dovoljno educiran za suradnju s učiteljem u } \\
\text { razredu. }\end{array}$} & $\mathrm{da}$ & 56 & 4,18 & 0,97 \\
\hline & ne & 112 & 3,70 & 1,08 \\
\hline \multirow{2}{*}{$\begin{array}{l}\text { 19. Smatram se dovoljno kompetentnim da mogu provoditi } \\
\text { individualizirane odgojno-obrazovne programe za učenike s teškoćama } \\
\text { samostalno bez pomoći učitelja. }\end{array}$} & da & 56 & 3,36 & 1,15 \\
\hline & ne & 112 & 3,05 & 1,16 \\
\hline \multirow{2}{*}{$\begin{array}{l}\text { 20. Zadovoljan sam podrškom koju mi pruža učitelj u mojoj odgojno- } \\
\text { obrazovnoj ustanovi. }\end{array}$} & da & 56 & 4,18 & 0,76 \\
\hline & ne & 112 & 4,36 & 0,85 \\
\hline \multirow{2}{*}{$\begin{array}{l}\text { 21. U suradnji s učiteljem planiram oblike i metode provođena } \\
\text { prilagođenog programa. }\end{array}$} & da & 56 & 3,75 & 1,22 \\
\hline & ne & 112 & 3,91 & 0,99 \\
\hline \multirow{2}{*}{$\begin{array}{l}\text { 22. Uvažavam iskustva učitelja/nastavnika u neposrednom radu s } \\
\text { učenicima s teškoćama. }\end{array}$} & $\mathrm{da}$ & 56 & 4,39 & 0,77 \\
\hline & ne & 112 & 4,61 & 0,64 \\
\hline \multirow{2}{*}{$\begin{array}{l}\text { 23. Smatram da suradnja nas PUN i učitelja u razredu olakšava } \\
\text { provođenje nastavnog plana i programa. }\end{array}$} & da & 56 & 4,61 & 0,49 \\
\hline & ne & 112 & 4,71 & 0,52 \\
\hline \multirow{2}{*}{$\begin{array}{l}\text { 24. Iz svog dosadašnjeg iskustva smatram da naš zajednički rad u razredu } \\
\text { pozitivno utječe na obrazovna postignuća i ponašanje svih učenika. }\end{array}$} & da & 56 & 4,57 & 0,62 \\
\hline & ne & 112 & 4,73 & 0,52 \\
\hline
\end{tabular}


Uočili smo da sudionici našeg istraživanja većinom (preko 65\%) nisu pohađali dodatne radionice/seminare nakon što su završili obvezan obrazovni program namijenjen pomoćnicima u nastavi te usvojili osnovna znanja iz područja edukacijskog uključivanja učenika s teškoćama u redovne škole, stoga je bilo važno utvrditi razlike između onih koji su se dodatno educirali u odnosu na sudionike koji su smatrali da imaju stečena potrebna znanja i kompetencije za rad s učenicima s teškoćama. Stavovi pomoćnika u nastavi koji su završili dodatne radionice/seminare statistički se značajno razlikuju od stavova ostalih sudionika na nekoliko varijabli iz istraživanja. Slijedom toga, uočavamo iz podataka prikazanih u Tablici 3. da se slažu s tvrdnjom da ih je učitelj na početku školske godine upoznao s dosadašnjim postignućima učenika kojemu su dodijeljeni $(t=1,65 ; d f=166 ; p<0,05)$, surađuju s učiteljem na način da zajednički planiraju izvannastavne aktivnosti na kojima sudjeluje učenik s teškoćama $(t=1,83 ; d f=166 ; p<0,05)$, zajedno češće dogovaraju uključivanje učenika s teškoćama u svakodnevne aktivnosti u razredu $(t=1,02 ; d f=166 ; p<0,05)$, rado prihvaćaju sugestije u načinu prilagodbe metoda i postupaka koji su primjereniji učeniku $\mathrm{s}$ obzirom na njegovu teškoću i sposobnost savladavanja nastavnog programa $(\mathrm{t}=$ $1,25 ; \mathrm{df}=166 ; \mathrm{p}<0,05)$, spremni su na promjene $\mathrm{u}$ svom radu $(\mathrm{t}=1,66 ; \mathrm{df}=166$; $p<0,05)$, korisnim smatraju zajedničko planiranje $s$ učiteljem aktivnosti u razredu prema preporukama stručnih službi škole ( $t=1,82 ; d f=166 ; p<0,05)$, često zajedno kreiraju razredno ozračje i potiču aktivnosti svih učenika u razredu $(t=1,16 ; d f=$ 166; $p<0,05)$, suradnju s učiteljem prihvaćaju na ravnopravnoj razini jer posjeduju potrebna znanja i kompetencije za rad $u$ inkluzivnom razredu $(t=1,79 ; \mathrm{df}=166 ; \mathrm{p}$ $<0,05)$ te naposljetku uvažavaju iskustva učitelja u odgojno-obrazovnom procesu i radu $s$ učenicima s teškoćama $(t=1,88 ; d f=166 ; p<0,05)$.

Dobiveni rezultati ne iznenađuju, moguće ih je objasniti pretpostavkom da su pomoćnici u nastavi koji su sudjelovali u programima osposobljavanja ili dodatnim radionicama i seminarima o radu s djecom/učenicima s teškoćama, bolje upoznati s školskom organizacijom, komunikacijom u školi, njihovom ulogom u odgojno-obrazovnom procesu, načinima i metodama rada i podrške učenicima s teškoćama u njihovoj što boljoj inkluziji u sustav redovnih škola. Samim time su svjesni svojih sposobnosti i potrebe za usvajanjem novih znanja i vještina vezanih kako općenito za rad s učenicima s teškoćama, tako i potrebe za ciljanim edukacijama koje se odnose na specifične teškoće kao i metode i postupke koje primjenjuju u svom svakodnevnom radu kroz podršku učenicima s teškoćama. 
Tablica 4. Razlike u stavovima pomoćnika u nastavi u odnosu na varijablu stupanj obrazovanja jednofaktorski model (ANOVA)

\begin{tabular}{|c|c|c|c|c|}
\hline Tvrdnje & df & MS & $\mathbf{F}$ & Sig. \\
\hline $\begin{array}{l}\text { 1. Na početku školske godine učitelj me je upoznao s } \\
\text { dosadašnjim postignućima učenika s teškoćama kojemu } \\
\text { sam dodijeljen/a. }\end{array}$ & 2 & 3,32 & 2,28 & 0,11 \\
\hline $\begin{array}{l}\text { 2. Smatram da je suradnja nas PUN i učitelja poticaj } \\
\text { ostalim učenicima da prihvate učenika s teškoćama kao } \\
\text { ravnopravnog člana razredne zajednice. }\end{array}$ & 2 & 0,44 & 1,02 & 0,36 \\
\hline $\begin{array}{l}\text { 3. U suradnji s učiteljem/nastavnikom zajednički planiramo } \\
\text { izvannastavne aktivnosti na kojima sudjeluje učenik s } \\
\text { teškoćama. }\end{array}$ & 2 & 7,53 & 5,35 & 0,00 \\
\hline $\begin{array}{l}\text { 4. Zajedno dogovaramo uključivanje učenika s teškoćama } \\
\text { u svakodnevne aktivnosti u razredu. }\end{array}$ & 2 & 5,87 & 7,40 & 0,00 \\
\hline $\begin{array}{l}\text { 5/Učitelj mi pomaže i daje sugestije u prilagodbi metoda i } \\
\text { postupaka primjerenih učeniku s teškoćama. }\end{array}$ & 2 & 6,52 & 8,17 & 0,00 \\
\hline 6. Učitelj me upozorava na pogreške u mojem radu. & 2 & 10,17 & 7,14 & 0,00 \\
\hline $\begin{array}{l}\text { 7. Učitelj me upućuje na stručnu službu škole ukoliko } \\
\text { zajedno ne dođemo do najboljeg rješenja za učenika s } \\
\text { teškoćama. }\end{array}$ & 2 & 3,12 & 2,47 & 0,09 \\
\hline $\begin{array}{l}\text { 8. Radionice o međusobnoj suradnji nas PUN i učitelja } \\
\text { pomogle bi boljem razumijevanju uloge PUN u razredu. }\end{array}$ & 2 & 1,31 & 3,43 & 0,03 \\
\hline $\begin{array}{l}\text { 9. Učitelj podržava moj angažman i kod ostalih učenika } \\
\text { u razredu kojima je potrebna pomoć u savladavanju } \\
\text { nastavnog gradiva. }\end{array}$ & 2 & 0,61 & 0,43 & 0,65 \\
\hline $\begin{array}{l}\text { 10. Prema uputama učitelja kontaktiram s roditeljima } \\
\text { i obavještavam ih o napretku ili zaostajanju učenika s } \\
\text { teškoćama. }\end{array}$ & 2 & 0,49 & 0,41 & 0,66 \\
\hline 11. Naš zajednički rad pridonio je kvalitetnijoj nastavi. & 2 & 0,50 & 1,02 & 0,36 \\
\hline $\begin{array}{l}\text { 12. Uključivanjem nas PUN učitelj ima više vremena za } \\
\text { druge učenike u razredu. }\end{array}$ & 2 & 3,75 & 6,82 & 0,00 \\
\hline $\begin{array}{l}\text { 13. Zajedno dogovaramo načine i oblike rada temeljene } \\
\text { na preporukama stručnih suradnika škole, vodeći računa } \\
\text { o specifičnostima u nastavnom procesu i sposobnostima } \\
\text { učenika s teškoćama. }\end{array}$ & 2 & 3,92 & 5,71 & 0,00 \\
\hline
\end{tabular}




\begin{tabular}{|c|c|c|c|c|}
\hline $\begin{array}{l}\text { 14. U svakodnevnom radu zajednički kreiramo ozračje za } \\
\text { poticanje aktivnosti svih učenika u razredu. }\end{array}$ & 2 & 7,49 & 7,12 & 0,00 \\
\hline $\begin{array}{l}\text { 15. Smatram da učenik s teškoćama bolje napreduje kada } \\
\text { je prisutna suradnja učitelja s PUN. }\end{array}$ & 2 & 0,00 & 0,01 & 0,99 \\
\hline $\begin{array}{l}\text { 16. Smatram da je potrebno organizirati još dodatnih } \\
\text { edukacija učiteljima kako bi stekli kompetencije za rad i } \\
\text { suradnju s PUN. }\end{array}$ & 2 & 0,21 & 0,45 & 0,63 \\
\hline 17. Uspješno surađujem s učiteljem u razredu. & 2 & 2,86 & 5,17 & 0,01 \\
\hline $\begin{array}{l}\text { 18. Smatram da sam dovoljno educiran za suradnju s } \\
\text { učiteljem u razredu. }\end{array}$ & 2 & 3,73 & 3,25 & 0,04 \\
\hline $\begin{array}{l}\text { 19. Smatram se dovoljno kompetentnim da mogu } \\
\text { provoditi individualizirane odgojno-obrazovne programe } \\
\text { za učenike s teškoćama samostalno bez pomoći učitelja. }\end{array}$ & 2 & 5,83 & 4,35 & 0,01 \\
\hline $\begin{array}{l}\text { 20. Zadovoljan sam podrškom koju mi pruža učitelj u } \\
\text { mojoj odgojno-obrazovnoj ustanovi. }\end{array}$ & 2 & 3,89 & 5,99 & 0,00 \\
\hline $\begin{array}{l}\text { 21. U suradnji s učiteljem planiram oblike i metode } \\
\text { provođena prilagođenog programa. }\end{array}$ & 2 & 9,25 & 8,74 & 0,00 \\
\hline $\begin{array}{l}\text { 22. Uvažavam iskustva učitelja/nastavnika u } \\
\text { neposrednom radu s učenicima s teškoćama. }\end{array}$ & 2 & 1,07 & 2,24 & 0,11 \\
\hline $\begin{array}{l}\text { 23. Smatram da suradnja nas PUN i učitelja u razredu } \\
\text { olakšava provođenje nastavnog plana i programa. }\end{array}$ & 2 & 0,17 & 0,65 & 0,52 \\
\hline $\begin{array}{l}\text { 24. Iz mog dosadašnjeg iskustva smatram da naš } \\
\text { zajednički rad u razredu pozitivno utječe na obrazovna } \\
\text { postignuća i ponašanje svih učenika. }\end{array}$ & 2 & 1,21 & 4,00 & 0,02 \\
\hline
\end{tabular}

Nadalje, utvrđena je statistički značajna razlika na razini $p<0,05$ na 13 tvrdnji skale PUN-učitelj na rezultatima stupanj obrazovanja koji smo podijelili u tri grupe: srednja škola, preddiplomski studij i diplomski studij (Tablica 4.). Na kraju analize, provodi se Post hoc Tukey HSD test kako bi se utvrdila razlika u srednjoj vrijednosti na razini $\mathrm{p}<0,05$ između pomoćnika u nastavi prema stupnju obrazovanja. Prezentirani rezultati u ovom dijelu radu sugeriraju da naknadna usporedba kroz Post hoc Tukey test pokazuje više srednje vrijednosti grupe 1 - srednja škola u odnosu na grupu 2 - preddiplomski studij i grupu 3 - diplomski studij. Post hoc analizom utvrđeno je da se pomoćnici u nastavi koji imaju završeno srednjoškolsko obrazovanje značajno razlikuju u procjeni stavova o međusobnoj suradnji s učiteljima u razredu kod dobivenih rezultata istraživanja na 13 tvrdnji: 
- značajno više potvrđuju sudjelovanje u zajedničkom radu oko dogovaranja s učiteljem načine uključivanja učenika s teškoćama u svakodnevne aktivnosti u razredu $F(2,167)=7,40 ; p=0,0$

- imaju značajno višu razinu suradnje u primjeni metoda i postupaka primjerenih učeniku s teškoćama, češće prihvaćaju pomoć i sugestije učitelja: $F(2,167)$ $=8,17 ; p=0,00$

- utvrđena je statistički značajna razlika kod stupnja obrazovanja na području suradnje kroz upozoravanje učitelja na pogreške u radu pomoćnika u nastavi: $F(2,167)=7,14 ; p=0,00$

- utvrđena je statistički značajna razlika na području suradnje i razumijevanja uloge pomoćnika u nastavi kroz pohađanje zajedničkih radionica s učiteljima radi stjecanja kompetencija potrebnih za rad s učenikom s teškoćama: $F(2,167)$ $=3,43 ; p=0,03$

- rezultati analize varijance ukazuju na značajnost razlika kod aktivnosti oko preuzimanja zadataka od učitelja čime mu ostavlja više vremena za ostale učenike u razredu: $F(2,167)=6,82 ; p=0,01$

- značajnost razlika uočena je i na području suradnje kod dogovora oko načina i oblika rada te prilagodbe nastavnog procesa sposobnostima učenika s teškoćama: $F(2,167)=5,71 ; p=0,00$

- značajnost razlika uočena na području suradnje kod kreiranja ozračja za poticanje aktivnosti svih učenika u razredu: $F(2,167)=7,12 ; p=0,00$. Ovaj podatak možemo protumačiti činjenicom da je upravo razredno ozračje prema percepciji pomoćnika u nastavi sa srednjoškolskim obrazovanjem važno za učenje i socijalizaciju učenika s teškoćama.

- rezultati analize varijance ukazuju na značajnost razlika na području suradnje kod pružanja podrške pomoćniku u nastavi u aktivnostima usmjerenim na prilagodbu metoda i postupaka u radu s učenikom s teškoćama: $F(2,167)=$ 5,14; $p=0,00$

- značajnost razlika uočena je na području suradnje kod provođenja prilagođenog programa učeniku s teškoćama: $F(2,167)=8,74 ; p=0,00$

- rezultati analize varijance ukazuju na značajnost razlika na području suradnje na poticanju zajedničkog rada prema boljim obrazovnim postignućima i ponašanju svih učenika u razredu: $F(2,167)=4,01 ; p=0,02$.

Dobiveni rezultati iz ovog dijela istraživanja i okolnosti prema kojoj razina obrazovanja pomoćnika u nastavi pridonosi razlikama u procjenama stavova o međusobnoj suradnji i načinima zajedničkog rada i podrške učeniku s teškoćama pomoćnika u nastavi i učitelja u inkluzivnom razredu, moguće je tumačiti dvojako. Čini se da niža razina formalnog obrazovanja (srednja škola) pridonosi boljoj suradnji pomoćnika u 
nastavi i učitelja u procesu provođenja inkluzivnog obrazovanja učenika s teškoćama u redovne škole. Post hoc analiza pokazala je da se, s obzirom na stupanj obrazovanja, kod stavova koji su u populaciji više u polju prihvaćanja, pomoćnici koji imaju završenu srednju školu izdvajaju od ostalih ispitanika s nižom razinom prihvaćanja. Najveća je pak razlika u prihvaćanju s obzirom na stav Smatram se dovoljno kompetentnim da mogu provoditi individualizirane odgojno-obrazovne programe za učenike s teškoćama samostalno bez pomoći učitelja. Ali, s druge strane, može se pretpostaviti da su pomoćnici u nastavi niže razine obrazovanja svjesni svojih kompetencija i nedostataka u obrazovanju te tu činjenici nadoknađuju dodatnim edukacijama i izobrazbom za rad s učenicima s teškoćama, što doprinosi poznavanju specifičnosti i posebnih potreba učenika. Nedvojbeno je da je kvalitetna suradnja jedan od najvažnijih čimbenika u osiguravanju inkluzije učenika s teškoćama u redovne škole.

Provedena istraživanja u ovom radu imala su za cilj utvrditi stavove o međusobnoj suradnji učitelja i pomoćnika u nastavi u inkluzivnom odgojno-obrazovnom procesu kao važnog čimbenika društvene i socijalne uključenosti djece s teškoćama u razvoju, utvrditi postoje li razlike u stavovima s obzirom na neka sociodemografska obilježja sudionika pomoćnika u nastavi. Analiza rezultata t-testa i analiza varijance (ANOVA) na skali PUN-učitelji na sudionicima s obzirom na sociodemografske varijable spol, godine života, razred koji učenik pohađa te radno iskustvo nisu se pokazale relevantnim nezavisnim varijablama za postojanje statistički značajnih razlika u procjeni stavova pomoćnika u nastavi prema suradnji s učiteljem u razredu, odnosno nije utvrđena statistički značajna razlika u odgovorima sudionika istraživanja na navedenim varijablama. Međutim, utvrđena je statistički značajna razlika u odgovorima na dvjema varijablama: radionice/seminari o radu s djecom/učenicima s teškoćama i stupanj obrazovanja pomoćnika u nastavi.

Dobiveni rezultati ukazuju na povoljne stavove pomoćnika u nastavi prema međusobnoj suradnji s učiteljima u inkluzivnom obrazovanju kao važnog čimbenika društvene i socijalne uključenosti djece s teškoćama u razvoju. Naime, pomoćnici u nastavi svjesni su nedostataka kako u svom obrazovanju potrebnih za rad s učenicima s teškoćama tako i provođenju odgojno-obrazovne inkluzije te da bez međusobne suradnje s učiteljem u razredu nije moguće provoditi uspješnu inkluziju. Poznavanje i razumijevanje posebnosti učenika s teškoćama, metoda i postupaka primjerenih njihovim sposobnostima i mogućnostima može doprinijeti boljoj organizaciji podrške učeniku s teškoćama od strane pomoćnika u nastavi u njegovoj inkluziji u odgojno-obrazovni sustav redovnih škola, kao i ulogu učitelja u tom procesu.

Kada govorimo o kompetencijama pomoćnika u nastavi za rad s djecom/učenicima s teškoćama, a s obzirom da je ovo istraživanje ukazalo na činjenicu da veći broj pomoćnika u nastavi ima završeno samo srednjoškolsko obrazovanje, da je potrebno 
u suradnji s stručnjacima iz područja pedagogije, psihologije, socijalnog rada i edukacijske rehabilitacije izraditi promjerene programe dodatnog obrazovanja pomoćnika u nastavi usmjerene prema konkretnim teškoćama i potrebama djece/učenika kao i prema njihovom osobnom razvoju kao odgojno-obrazovnog pomoćnog djelatnika. Isto tako, valja naglasiti potrebu neprestanog stručnog usavršavanja i cjeloživotnog učenja samih učitelja iz područja odgojno-obrazovne inkluzije u cilju osiguranja dodatnog vremena za provedbu individualizacije nastave u radu s djecom s teškoćama i suradničkog rada s pomoćnicima u nastavi, s obzirom na njihove stečene kompetencije kroz inicijalno obrazovanje. Evidentno je da su pomoćnici u nastavi svjesni važnosti svoje uloge u podršci učeniku s teškoćama u redovnom odgojno-obrazovnom procesu i njihovog kontinuiranog svakodnevnog neposrednog kontakta s učiteljem i ostalim učenicima u razredu, ali i obveza ili očekivanja koja proizlaze iz njihovog uvođenja u redovnu nastavu. Radi toga je važno osigurati sustavnu edukaciju pomoćnika u nastavi i učitelja o senzibiliziranosti za rad s djecom s teškoćama. Naime, posjedovanje i primjenjivanje znanja i vještina vezanih uz komunikaciju, zajednički rad i suradnički odnos, usklađenosti rada te ispravan odabir metoda i postupaka kao i individualiziran pristup u planiranju aktivnosti, pokazali su se ključnim elementima u ovom istraživanju za dobrobit svih učenika u razredu, a posebno učenika s teškoćama.

Isto tako, valja naglasiti, kako bi se ispitala učinkovitost suradnje i partnerstva, potrebno je ispitati obje skupine u partnerstvu. Stoga je isti skup tvrdnji, uz eventualne prilagodbe, potrebno postaviti i učiteljima u redovnim školama kako bi usporedbom rezultata dobili podatke što bi valjalo promijeniti i na koji način u pogledu izrade nastavnih planova i programa, suradnje dionika i podrške te koje su prepreke za bolju i kvalitetniju inkluziju djece s teškoćama u redovne škole.

\section{OGRANIČENJA I PREPORUKE ZA DALJNJA ISTRAŽIVANJA}

Prikazano istraživanje omogućilo je stjecanje uvida u međusobnu suradnju učitelja i pomoćnika u nastavi te predstavlja doprinos razumijevanju učinaka provođenja odgojno-obrazovne inkluzije kako na učenike s teškoćama tako i na sve ostale učenike u razredu. Međutim, prilikom interpretiranja rezultata, treba obratiti pažnju na nekoliko uočenih ograničenja. Pomoćnici u nastavi koji su sudjelovali u ovom istraživanju s područja su Istarske županije te se rezultati i stavovi dobiveni na tom uzorku i interpretirani u ovom istraživanju ne moraju odnositi na stavove sudionika iz drugih područja ili regija. Isto tako, broj sudionika s kojim smo raspolagali bio je ograničen mjestom prikupljanja podataka, odnosno skupom na kojem su sudjelovali. 
Naime, prvobitno je bilo planirano da u istraživanju sudjeluju svi pomoćnici u nastavi evidentirani u bazama podataka osnovnih i srednjih škola na području Istarske županije, a koji su provodili natječaje za zapošljavanje pomoćnika u nastavi. Međutim, ta mogućnost je otklonjena s obzirom na nedostupnost takvih podataka prema Općoj uredbi o zaštiti podataka, te smo se odlučili na pomoćnike u nastavi koji su sudjelovali u organiziranoj panel raspravi, gdje su dali svoj pristanak na sudjelovanje u istraživanju.

Preporuka za buduća istraživanja odnosi se na instrument Skala stavova o suradnji pomoćnika u nastavi i učitelja (PUN-učitelj) koji se može koristiti u istraživanjima čimbenika koji pridonose socijalnoj interakciju djece/učenika s teškoćama u okruženju vršnjaka, kako bi ih kroz kvalitetan i primjeren odgoj i obrazovanje osposobili za samostalan život. U svakom slučaju, sljedeći istraživački korak vezan je uz re-validaciju ovdje predložene verzije skale kod učitelja. Bilo bi zanimljivo posebno se osvrnuti na stavove učitelja prema međusobnoj suradnji i inkluziji te ih povezati s njihovim iskustvom i drugim relevantnim varijablama.

\section{ZAKLJUČAK}

Odgojno-obrazovna inkluzija učenika s teškoćama u razvoju u redovne škole omogućava na temelju stručne procjene njihovih posebnih odgojno-obrazovnih potreba u skladu s njihovim sposobnostima uz podršku učitelja i pomoćnika u nastavi usvajanje znanja i vještina kako bi stekli samostalnost i socijalu uključenost. Aktivnosti koje pomoćnici u nastavi provode, a koji opisuju njihovu spremnost na podršku učitelju, odnose se na dobrobit inkluzije i potrebu podizanja razine obrazovnih postignuća i emocionalnog funkcioniranja učenika s teškoćama u redovnim školama.

lako su u ovom istraživanju uočena metodološka ograničenja koja smo naveli, rezultati koje smo dobili mogu poslužiti boljem razumijevanju potreba i prednosti obrazovne inkluzije djece s teškoćama u redovne škole kao i veće angažiranosti svih dionika. Valja naglasiti da je temelj inkluzivnog obrazovanja prihvaćanje različitosti i time se kroz koncept podrške suprotstavlja svim oblicima diskriminacije i promiče vrijednosti na kojima se gradi humano društvo temeljeno na međusobnom prihvaćanju i uključivanju. Nadalje, ovime se istraživanjem želi potaknuti interes zajednice i potreba odgojno-obrazovne inkluzije djece/učenika s teškoćama u sustav redovnih škola kako bi im se omogućio razvoj te društvena i socijalna uključenost poštujući njihove mogućnosti i sposobnosti koje posjeduju. Konačno, kako se u cijelom radu ističe važnost uključivanja i socijalizacija djece/učenika s teškoćama uz podršku pomoćnika u nastavi i međusobna suradnja svih uključenih u odgojno-obrazovni proces, istraživanja u ovom području omogućavaju unapređenje položaja ove ranjive skupine kroz promjene u pristupu samom obrazovanju. 


\section{LITERATURA}

1. Angelides, P., Constantinou, C. \& Leigh, J. (2009). The role of paraprofessionals in developing inclusive education in Cyprus. European Journal of Special Needs Education, 24 (1), 75-89.

2. Bentham S. \& Hutchins, R. (2006). Practical tips for teaching assistants. New York: Routledge.

3. Blatchford, P., Russell, A. \& Webster, R. (2011). Reassessing the impact of teaching assistants: How research challenges practice and policy. London: UK Routledge.

4. Booth, T. (2000). Controlling the agenda: policies on inclusion and exclusion in England. In: Armstrong, D., Armstrong, F. \& Barton, L. (eds.), Policy, contexts and comparative perspectives. London: Fulton. Citirano u NESSE (2012).

5. Brand, E. (2004). Teacher and teacher assistant perceptions of their relationship. Master Thesis. Saskatoon: University of Saskatchewan.

6. Bouillet, D. (2010). Izazovi integriranog odgoja i obrazovanja. Zagreb: Školska knjiga.

7. Daniels, V. I. \& McBride, A. (2001). Paraeducators as critical team members: Redefining roles and responsibilities. NAASP Bulletin, 85 (623), 66-74.

8. Chopra, R. V. \& French, N. K. (2004). Paraeducator relationships with parents of students with significant disabilities. Remedial and Special Education, 25 (4), 240-251.

9. Cremin, H., Thomas, G. \& Vincett, K. (2005). Working with teaching assistants: Three models evaluated. Research Papers in Education 20 (4), 413-432.

10. Devecchi, C. \& Rouse, M. (2010). An exploration of the features of effective collaboration between teachers and teaching assistants in secondary schools. British Journal of Learning Support, 25 (2), 91-99.

11. Drandić, D. \& Lazarić, L. (2018). Pomoćnik u nastavi u inkluzivnom obrazovanju. Pula: Sveučilište Jurja Dobrile u Puli.

12. Drandić, D. (2017). Uloga pomoćnika u nastavi u provođenju inkluzivnoga obrazovanja. Napredak, 158 (4), 439-459.

13. Gerlach, K. (2016). Let's team up: What every paraprofessional needs for student success and effective teamwork. Seattle, Washington: Pacific Training Associates.

14. Giangreco, M. F., Edelman, S. W., Broer, S. M. \& Doyle, M. B. (2001). Paraprofessional support of students with disabilities: Literature from the 
past decade. Exceptional Children, 68 (1), 45-63.

15. Giangreco, M. F. (2009). Critical issues brief: Concerns about the proliferation of one-to-one paraprofessionals. Arlington, VA: Council for Exceptional Children, Division on Autism and Developmental Disabilities.

16. Giangreco, M. F., Suter, J. C. \& Doyle, M. B. (2010). Paraprofessionals in inclusive schools: A review of recent research. Journal of Educational \& Psychological Consultation, 20 (1), 41-57.

17. Greenspan, S. I. \& Wieder, S. (2003). Dijete s posebnim potrebama: Poticanje intelektualnog i emocionalnog razvoja. Lekenik: Ostvarenje.

18. Igrić, Lj. \& Fuček, I. (2012). Priručnik za organizaciju rada pomoćnika u nastavi. Zagreb: Centar inkluzivne potpore IDEM.

19. Igrić, Lj. (2015a). Uvod u inkluzivnu edukaciju. U: Igrić, Lj. (ur.), Osnove edukacijskog uključivanja - Škola po mjeri svakog učenika je moguća. Zagreb: Sveučilište u Zagrebu, Edukacijsko-rehabilitacijski fakultet i Školska knjiga, 30-50.

20. Igrić, Lj. (2015b). Inkluzivna edukacija, hrvatski kontekst, istraživanja i programi podrške. U: Igrić, Lj. (ur.) Osnove edukacijskog uključivanja-Škola po mjeri svakog djeteta je moguća. Zagreb: Edukacijsko-rehabilitacijski fakultet Sveučilište u Zagrebu i Školska knjiga, 296-327.

21. Ivančić, Đ. \& Stančić, Z. (2013). Stvaranje inkluzivne kulture škole. Hrvatska revija za rehabilitacijska istraživanja, 49 (2), 139-157.

22. Jones, C. R., Ratcliff, N. J., Sheehan H. \& Hunt, G. H. (2012). An analysis of teachers' and paraeducators' roles and responsibilities with implications for professional development. Early Childhood Education Journal, 40 (1), 19-24.

23. Karamatić Brčić, M. (2011). Svrha i cilj inkluzivnog obrazovanja. Acta ladertina, 8 (1), 39-47.

24. Logan, A. (2006). The role of special needs assistant supporting pupils with special educational needs in Irish mainstream primary schools. Support for Learning, 21 (2), 92-99.

25. Miles, S. (2000). Enabling Inclusive Education: Challenges and Dilemmas. Enabling Education Network EENET. Preuzeto s: http://www.eenet.org. uk/resources/docs/bonn_2.php (22.1. 2019.)

26. Mistry, M., Burton, N. \& Brundrett. M. (2004). Managing LSAs: An evaluation of the use of learning support assistants in an urban primary school. School Leadership and Management, 24 (2), 125-137.

27. Morgan, J., Ashbaker, B. Y. \& Young, J. R. (2001). Teaming, supervision and evaluation: teacher-paraeducator team perspectives of their teaching. Utah: ERIC 
28. Pickett, A. L. (1999). Paraeducators: Factors that influence their performance, development and supervision. Preuzeto s: http://ericec.org/digests/ e587.htm (22.1.2019.).

29. Pickett, A. L. \& Gerlach, K. (2003). Supervising paraprofessionals in educational settings: A team approach. 2nd Edition. Austin, TX: PRO-ED.

30. Pravilnik o pomoćnicima u nastavi i stručnim komunikacijskim posrednicima (2018). Narodne novine, 102/2018.

31. Puškarić, F., Vrban, S., Zbukvić Ožbolt, S. \& Vragović, A. (2017). Priručnik za pomoćnike u nastavi/stručne komunikacijske posrednike. Zagreb: Grad Zagreb.

32. Radetić-Paić, M. (2015). Theory and practice of integrated education from the perspective of university teachers: How much do we really know? Croatian Journal of Education, 17 (1), 195-204.

33. Riggs, C. G. \& Mueller, P. H. (2001). Employment and utilization of paraeducators in inclusive settings. The Journal of Special Education, 35 (1), 54-62.

34. Schlapp, U., Davidson, J. \& Wilson, V. (2003). An "extra pair of hands"?: Managing classroom assistants in Scottish primary schools. Educational Management and Administration, 31 (2), 189-205.

35. Skočić Mihić, S., Vlah, N. \& Šokić, M. (2018). Stavovi odgajatelja i učitelja prema inkluziji djece s oštećenjem sluha. Hrvatska revija za rehabilitacijska istraživanja, 54 (1), 69-82.

36. Suter, J. C. \& Giangreco, M. F. (2009). Numbers that count: Exploring special education and paraprofessional service delivery in inclusionoriented schools. Journal of Special Education, 43 (2), 81-93.

37. Takala, M. (2007). The work of classroom assistants in special and mainstream education in Finland. British Journal of Special Education, 34 (1), 50-57.

38. Thompson, D. M. (2002). Teachers and teacher assistants: Building effective relationships. Master Thesis. Alberta: University of Alberta.

39. UNESCO (1994). The Salamanka statement and framework for action on special needs education. Preuzeto s: http://www.unesco.org/education/ pdf/SALAMA_E.PDF (22.1.2019.).

40. Wagner Jakab, A., Lisak, N. \& Cvitković, D. (2016). Učiteljska procjena pokazatelja kvalitete inkluzije. U: Potić, S., Golubović, Š. \& Šćepanović, M. (ur.), Inclusive theory and practice international thematic collection of papers. Novi Sad: Society of defectologists of Vojvodina, 39-50. 
41. Wallace, T., Shin, J., Bartholomay, T. \& Stahl, B. J. (2001). Knowledge and skills for teachers supervising the work of paraprofessionals. Exceptional Children, 67 (4), 520-533.

42. Werts, M. G., Harris, S., Tillery, C. Y. \& Roark, R. (2004). What parents tell us about paraeducators. Remedial and Special Education, 25 (4), 232-239.

43. Zakon o odgoju i osnovnom obrazovanju u SR Hrvatskoj, Narodne novine, 4/1980. 
Dijana Drandić

Mirjana Radetić Paić

Juraj Dobrila University of Pula

Faculty of Education

\section{COOPERATION IN INCLUSIVE SCHOOLS: HOW DO LEARNING SUPPORT TEACHERS EVALUATE THEIR COOPERATION WITH CLASS TEACHERS?}

\section{ABSTRACT}

The educational inclusion of pupils with disabilities into regular schools enables, based on the professional evaluation of their special educational needs, with the support of teachers and learning support teachers, and in line with their abilities, the acquisition of knowledge and skills necessary to become self-sufficient and socially included. The aim of this research was to gain insight into the cooperation work of learning support teacher and teacher and, from the learning support teacher's perspective to explore their views on mutual cooperation in the implementation of educational inclusion of pupils with disabilities in regular classes, then to examine the relationship of learning support teachers attitudes with their sociodemographic characteristics. The obtained results indicate favorable attitudes of learning support teachers towards cooperation with teachers. As well as the fact that the majority of learning support teachers have only completed secondary education. It seems that the lower level of formal education of learning support teachers (secondary school) as well as attending seminars and workshops on educational inclusion and developmental disabilities contribute to better mutual cooperation. The results of the conducted analysis have shown the existence of differences in attitudes among participants with regard to two sociodemographic variables: workshops/seminars about working with children/pupils with disabilities and the learning support teachers' level of education. Anyhow, it is important to emphasize the collaboration and supporting relationship between learning support teachers and teachers who can ensure sufficient psychological, pedagogic, program-organisational, didactic-methodical and social possibilities of the school's inclusive activity. This research special contribution is reflected in the scientific cognition that inclusive education supports the development of inclusive values and the acceptance of differences among pupils, but also the progress of this vulnerable group through changes in access to education process.

Key words: inclusion, education, socialisation, collaboration, pupil with disabilities. 